\title{
Espetáculo à mesa: midiatização da cozinha nos reality shows de gastronomia ${ }^{1}$
}

\section{A show on the table: the kitchen's mediatization in cooking reality TV shows}

\author{
Viviany Moura CHAVES ${ }^{2}$ \\ Alexsandro Galeno Araújo DANTAS ${ }^{3}$
}

\begin{abstract}
Resumo
Os reality shows têm conferido um aumento da visibilidade midiática dada ao tema da gastronomia, configurando-se numa estratégia convidativa para unir dois fortes elementos: o comer e o jogar. Este artigo trata-se de um ensaio teórico que tem como objetivo discutir como a cozinha, inserida no contexto de hipervisibilidade midiática, se tornou um espetáculo televisivo contemporâneo. Ao ser modelizada pelos meios de comunicação, a cozinha atinge seu caráter espetacular, migrando dos espaços convencionais dos lares e dos restaurantes para os shows televisivos de gastronomia. A presente abordagem sugere compreender as distintas ressignificações alcançadas pelo $\mathrm{O}$ ato de comer e cozinhar frente às telas do entretenimento alimentar.
\end{abstract}

Palavras-chave: Espetáculo. Midiatização. Gastronomia. Entretenimento alimentar. Reality show.

\begin{abstract}
Reality shows have helped increase the visibility of cooking, providing a strategy for combining two strong elements: eating and playing. This theoretical essay aims to discuss how the kitchen, placed in a context of media hypervisibility, has started to represent a contemporary televised spectacle. When modeled by the media, the kitchen develops a

\footnotetext{
${ }^{1}$ Pesquisa financiada pela Coordenação de Aperfeiçoamento de Pessoal de Nível Superior (CAPES) durante curso de Mestrado no Programa de Pós-Graduação em Ciências Sociais da UFRN.

2 Doutoranda pelo Programa de Pós-Graduação em Ciências Sociais da Universidade Federal do Rio Grande do Norte (UFRN), Mestre em Ciências Sociais pela mesma instituição (2018), graduada em Nutrição pela Universidade Federal de Campina Grande (2016). Atua como professora substituta do Departamento de Nutrição da UFRN (Campus Central), onde também presta assessoria como nutricionista ao Centro Colaborador em Alimentação e Nutrição do Escolar (CECANE/UFRN). E-mail: vivianymourachaves@ hotmail.com. ORCID: 0000-0002-9654-7152.

${ }^{3}$ Professor associado da Universidade Federal do Rio Grande do Norte, coordenador do Programa de Pós Graduação em Ciências Sociais e Presidente da Cooperativa Cultural Universitária. Graduou-se em Geografia na UFRN, é Mestre em Ciências Sociais pela mesma instituição e Doutor em Ciências Sociais pela Pontifícia Universidade Católica de São Paulo. Tem Pós-Doutorado pela Universidade de São Paulo na área de linguística, letras e artes. E-mail: alexgalenno@gmail.com. ORCID: 0000-0001-5103-0339.
} 
spectacular character, migrating from the conventional spaces of the homes and restaurants to television cooking shows. Our approach suggests that it is important to understand the different meanings conveyed by the act of eating and cooking in front of the screens of food entertainment.

Keywords: Spectacle. Mediatization. Gastronomy. Food entertainment. Reality show.

\section{Intróito: luz, câmera e cozinhando}

No atual cenário de hipervisibilidade midiática, a alimentação tem ocupado espaços para além das mesas dos comensais, despertando influência sobre temas que relacionam o comer e o cozinhar. Nas últimas décadas, houve uma explosão da mídia de entretenimento alimentar, alcançando não apenas as páginas da mídia impressa, mas, sobretudo, os diversos sites que fornecem diariamente receitas e vídeos com demonstrações de técnicas de culinária. Do mesmo modo, nas telas da mídia televisiva, percebe-se também uma busca significativa da audiência consumidora de reality shows que, cada vez mais, tem incorporado em suas pautas apresentações relacionadas à culinária e gastronomia.

No Brasil, os reality shows têm conferido um aumento do espaço da visibilidade da gastronomia. A comida e a cozinha entraram para as telas do glamour, da exacerbação estética e da sofisticação, sendo consideradas espetáculos da contemporaneidade (SANT'ANNA, 2003). O fenômeno de espetacularização ao redor da comida converte o alimento em um novo formato, ao fazer uso das mídias para se enaltecer na forma de espetáculo (JACOB, 2013). Neste universo, o espetáculo não é um conjunto de imagens, mas uma relação social mediada por imagens, como discute Debord (1997).

As imagens mediadas pela cultura da midiatização querem algo além de sua suposta exposição superficial. A ideia é buscar novas referências para os indivíduos, ainda que seja numa ética lúdica e consumista da vida (LIPOVETSKY, 1989). Desse modo, a gastronomia transforma-se em um produto midiático (na forma de reality show) e, também, em uma mercadoria, sendo capaz de migrar da cozinha para o imaginário social (LAVINAS, 2015). Este produto é capaz de produzir uma visibilidade para os seus consumidores e, então, demarca no mundo mercados de singularidades em que a qualidade é um atributo de valor cultural, construído e incorporado pelos seus 


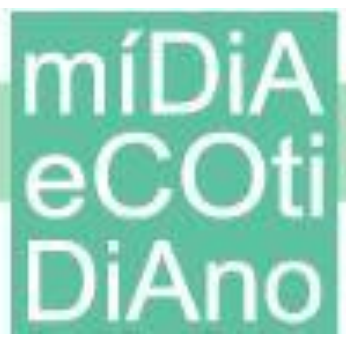

consumidores (KARPIK, 2008). Logo, a mídia e o mercado operam na sociedade uma forma de ser, viver e se relacionar, apoderando-se de um tema de interesse coletivo para garantir sua alta visibilidade e comunicabilidade.

No universo retratado nos programas do tipo reality show são propagadas mensagens que envolvem questões mais complexas do que o simples ato de cozinhar. A mobilização do mercado e dos meios de comunicação para enaltecer a gastronomia como objeto do imaginário social, do desejo, da realização profissional e do simbólico, tem possibilitado o seu caráter espetacular. Tal visibilidade proporciona a (des)construção de signos ligados ao ato de comer e cozinhar, potencializando o surgimento de produtos midiáticos que incentivem contemplar a comida como um instrumento de guerra e a cozinha como um laboratório de experimento, como ocorre na maioria dos reality shows. Assim sendo, o espetáculo gastronômico enaltece a cozinha como um espaço de competição.

Um dos programas de tendência gastronômica que tem mais repercutido nos últimos anos é o Masterchef. A franquia ganhou sua primeira versão no Brasil em 2014, em canal aberto na Rede Bandeirantes de televisão e, em pouco tempo, já se tornou um sucesso na mídia televisiva e nos sites de redes sociais. Frequentemente, nas páginas do Facebook, Instagram e Twitter são compartilhadas informações referentes ao programa. $\mathrm{Na}$ transmissão da final da segunda temporada do reality show, um recorde foi batido no Twitter: em menos de duas horas, mais de 1,7 milhões de internautas haviam mencionado a hashtag \#MasterChefBR.

Ao tomar o Masterchef como um exemplo prático de espetacularização alimentar, é possível perceber que o público que assiste ao programa contempla pessoas com ou sem aptidão ou gosto por cozinhar. O reality show apela para algo que é essencial à condição vital e cultural do homem: o ato de comer. Sabe-se que a comida compartilha de um gosto tanto da necessidade - da ordem da subsistência - quanto do luxo - da ordem do prazer, permeado pelo desejo (BOURDIEU, 2007). Em todas as situações em que a comida esteja presente, o ato de comer é algo realizado por todos os seres humanos, até mesmo por aqueles que não sabem cozinhar. Dessa forma, o programa utiliza de uma estratégia convidativa unindo dois fortes elementos: o comer e o jogar. 
Neste espetáculo, a comida tem o dever de atingir a categoria de gourmet, em que uma sobremesa não pode ser um simples chocolate, mas uma ganache de chocolate belga com flor de sal e pimenta rosa, numa combinação e apresentação perfeita de élégance e délicatesse. Além disso, a cozinha se torna um lugar de competição, agressividade, pressão e desafio, onde os participantes sofrem com críticas ácidas, destrutivas e irônicas por parte dos jurados do reality show (LAVINAS, 2015).

Diante dessa premissa, a ideia de pensar sobre a cozinha inserida num cenário crescente de midiatização foi o ponto de partida para compreender as distintas ressignificações que o comer e cozinhar alcançaram frente às telas do entretenimento alimentar. Portanto, o presente artigo trata-se de um ensaio teórico que buscou analisar sobre como a cozinha, em um cenário midiático, se tornou um espetáculo televisivo contemporâneo.

\section{O caráter espetacular dos shows de gastronomia}

O modo de viver da sociedade moderna baseia-se na transmissão instantânea da informação e na velocidade com que se é reproduzida. Não é estranho que as transformações culturais, econômicas e sociais ligadas a este fenômeno tenham afetado também os modos de comer. Atualmente, as assinaturas gastronômicas tornaram-se uma referência da modernidade, ocupando um espaço significativo no cerne dos cenários midiáticos.

Ao longo dos anos, a gastronomia acompanhou os avanços tecnológicos de comunicação, inserindo-se, assim, na mídia. Ao tratar da mídia enquanto um conjunto dos meios de comunicação produzidos em massa e veiculados para uma massa indistinta de público, é necessário compreender que o impacto social do desenvolvimento das redes de comunicação e do fluxo de informação implica na criação de novas formas de ação, de interação no mundo social e de relacionamentos do sujeito com os outros e consigo (THOMPSON, 1998; MARCONDES FILHO, 2009). Ao fazer uso das mídias, os sujeitos são capazes de interagir uns com os outros ainda que fisicamente ausentes.

Ao pensar em quem produz a informação, geralmente a figura do jornalista tem um papel central no sistema midiático. No entanto, com a difusão do acesso aos meios de comunicação, principalmente os sites de redes sociais, temos diversos atores que 
cumprem este papel: blogueiros, digital influencers, youtubers ou qualquer pessoa que possua visibilidade midiática. A partir disso, observa-se um movimento para o acesso democratizado a informação, no qual a internet se tornou o carro-chefe de uma sociedade formada por redes de interação midiática. Todavia, ainda que exista pouco acesso a estes meios, o sujeito precisa pertencer a eles, isto é, se tornar um membro ativo que discute, contribui, reflete e colabora para a construção do conhecimento da rede a qual pertence. O desafio é transformar informação em conhecimento.

Para Edgar Morin (2003), não se pode confundir informação com conhecimento, pois o conhecimento é a informação organizada, sendo capaz de situar, contextualizar e globalizar dados recebidos anteriormente. Assim sendo, enquanto a comunicação relaciona-se a uma questão de meios, a compreensão é uma questão de fins, ambas são remetidas para questões éticas e políticas.

\footnotetext{
Essa unidade elementar da informação, chamada de bit, só adquire sentido se for integrada a um conhecimento que a organiza. $\mathrm{O}$ conhecimento é aquilo que permite situar a informação, contextualizála e globalizá-la, ou seja, inseri-la num conjunto. Ou somos submetidos a uma informação pletórica inorganizada que, rapidamente, esquecemos, porque somos incapazes de estruturá-la; ou a informação é organizada demais, ou seja, selecionada por um sistema teórico rígido (MORIN, 2003, p. 124).
}

Em relação ao que se produz, percebe-se que a mídia possui duas funções importantes: informar e entreter. Dessa maneira, a informação é analisada a partir do que se fala (conteúdo) e como se fala (discurso), buscando identificar temas abordados, sua frequência e mensagens explícitas ou implícitas presentes nos diversos canais dos meios de comunicação (DORTIER, 2010).

Os efeitos dos media propagados na era atual têm sido uma questão bastante discutida no campo da comunicação e da sociologia. Entre os anos de 1930 e 1945, a teoria dominante era de que a mídia de massa (mass media) tinha um efeito imediato, massivo prescritivo sobre a audiência. Os sociólogos da Escola de Frankfurt consideravam a mídia um instrumento de difusão da ideologia dominante, em que sua influência consistiria numa uniformização do pensamento e dos comportamentos no sentido de aceitação do sistema capitalista (DORTIER, 2010). Anos mais tarde, Paul Lazarsfeld e colaboradores (1969) 


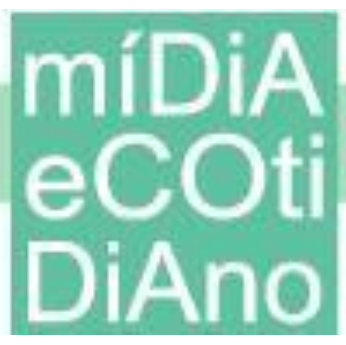

mostram por meio de estudos empíricos que a influência da mídia depende de opiniões preexistentes e da teia de relações interpessoais do receptor. Desse modo, os efeitos da mídia não são diretos, mas são filtrados e limitados na recepção (espectador).

Ainda buscando avançar nessa questão, os pesquisadores Liebes e Katz (1993) realizaram estudos de recepção - que buscam compreender como os conteúdos da mídia são retidos, restituídos e interpretados pelos receptores - e apresentaram que a influência da mídia estaria condicionada principalmente à reação do receptor, esta ligada à cultura de seu grupo social ou de sua comunidade. Morin (2003), a respeito desta discussão, nos faz lembrar que em 1930, nos Estados Unidos, especulava-se que o cinema estimulava a violência e, na sequência, esta mesma crítica foi feita contra a televisão.

Shakeaspeare já mostrava o lado obscuro da humanidade e não podemos acusá-lo de estimular a violência. (...) Basta dar uma olhada nas tragédias gregas, em 'Medéia', na história de Édipo, homem que mata o pai e faz sexo com a mãe. Será que isso faz aumentar o número de incestos? Não (MORIN, 2003, p.14).

Morin procura explicar que o problema da comunicação é mesmo de civilização e que a vida comporta uma dimensão lúdica que deseja a consumação por jogos, competições ou divertimentos. A televisão, o cinema e a internet são, por exemplo, parte desta dimensão.

É diante deste cenário que a crescente midiatização, isto é, “o processo de expansão dos diferentes meios técnicos e as inter-relações entre a mudança comunicativa dos meios e a mudança sociocultural", tem operado por meio de diversos mecanismos (GOMES, 2016). Braga (2006) ressalta que a midiatização ocorre em dois âmbitos sociais: no microssocial e no macrossocial. No primeiro âmbito são tratados processos sociais específicos que passam a se desenvolver segundo às lógicas da mídia. No segundo, refere-se ao processo de adaptação e simulação da própria sociedade à lógica medial, ou seja, os sistemas e processos sociais não "substituem" outros, mas absorvem, redirecionam e dão outro desenho.

Frente às circunstâncias desse contexto, a gastronomia permeia o atual cenário de midiatização quando deixa o espaço tradicional da cozinha e passa a criar estratégias comunicativas em outros ambientes. O reality show é um tipo de produto midiático que 


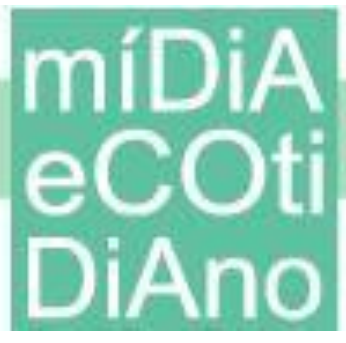

acontece no âmbito das interações, pois concede ao público o poder decisório daquele que, por exemplo, vai permanecer ou sair do programa, quem irá ganhar ou perder. É um universo de possibilidades mediante a participação interativa. Além disso, o reality show opera sobre o imaginário televisivo, como comenta Suzana Kilpp (2008), uma vez que por meio da seleção de jogadores, da invenção de pontos fortes e fracos dos participantes, dos discursos proferidos, cria-se um cenário de personagens midiáticos em que o público decide por aqueles que possuem uma afinidade, a partir de critérios de seleção que são de ordem tanto individual quanto coletiva.

No caso do Masterchef, a decisão de quem vence não é dada às mãos do público. Entretanto, o programa atua para além da mídia televisiva, interagindo com os espectadores através das redes sociais. O Twitter foi a principal rede que acompanhou o reality show, seguido pelo Instagram e Facebook. Ao final da primeira temporada do Masterchef Profissionais Brasil, que foi transmitida ao vivo, o nome do vencedor foi divulgado primeiramente nas redes sociais, antes mesmo de anunciar para os participantes na televisão. Dessa forma, observa-se que os sujeitos não se satisfazem mais com atitudes passivas diante da televisão, eles buscam ser uma parte ativa desse processo, mediante o envolvimento, a ação, a torcida. A reconfiguração dos formatos televisuais diante de uma sociedade midiática solicita um telespectador mais participativo (JENKINS, 2009). A televisão, neste caso, constitui-se como a principal mídia formadora do espetáculo.

Em a Sociedade do espetáculo (1997), Guy Debord ressalta que o espetáculo é a esfera da sociedade na qual as relações passam a ser mediadas por imagens, ou seja, as relações dependem da visibilidade. Se antes as relações ocorriam de maneira direta, na sociedade moderna acontece de forma mediada, visto que não há mais uma separação do mundo real e do mundo ficcional, pois ambos se constituem em um só, como destaca o autor: "a realidade surge no espetáculo, e o espetáculo é real” (DEBORD, 1997, p. 15).

Nesta perspectiva, o espetáculo além de ser a dissolução da fronteira entre o eu e o mundo, é também a “[...] supressão dos limites do verdadeiro e do falso pelo recalcamento de toda verdade vivida, diante da presença real da falsidade garantida pela organização da aparência” (DEBORD, 1997, p. 140). Isto acontece no universo do reality show, pois o que é verdadeiro e o que é falso se misturam no mundo da ficção e da realidade ao ponto de não percebemos. De acordo com Tonin (2014): 
A mediação imagética apaga a autenticidade, o concreto do vivido, ou seja, deixa de ser verdadeira a relação entre homem e mundo. As relações sociais se estabelecem entre seres alienados, apagados em suas individualidades, seres que vivem necessidades socialmente sonhadas, vivem por procuração, através de vedetes do espetáculo que representam o que não são. Estas relações mediadas acabam com a potência criativa do sujeito, ele não faz nada além de naufragar o olho na superfície da tela (TONIN, 2014, p. 12).

Percebe-se que os consumidores de reality show são inseridos também no âmbito do programa, no sentido de que a interação entre jogador e espectador, por vezes, se misturam e a vida assistida vem a ser a vida que se deseja viver. O espetáculo possui um caráter sedutor por apresentar a positividade e o inacessível ao público, podendo ser considerado a negação da vida, a vida social como aparência, pois não deseja chegar a nada que não seja ele mesmo (DEBORD, 1997).

Nesta perspectiva, os reality shows contemporâneos em que a comida se torna um espetáculo televisivo, existe uma lacuna que separa o espectador da realidade da cozinha profissional. A maioria dos programas e reality shows de gastronomia apresentam o espaço da cozinha de forma maquiada, vista somente pelos holofotes e pelo glamour que a posição de um chef de cozinha tem ocupado na sociedade. Acontece que a realidade na cozinha profissional é marcada pelo trabalho árduo dentro de um ambiente hostil, em que o autoritarismo e as hierarquias de poder ocorrem frequentemente.

A mídia de entretenimento alimentar ofereceu aos consumidores uma experiência de lazer, um espetáculo a ser visto. No entanto, tais consumidores têm pouco entendimento do trabalho realizado nas cozinhas de um restaurante requintado, desconhecendo o desafio de recriar os pratos que admiram. Ao que parece, os indivíduos não estão preparados para superar ou pensar sobre as questões hostis que ainda cercam os contextos das cozinhas, sejam elas domésticas ou profissionais.

Admite-se também que tal cobertura da mídia trouxe uma atenção merecida para uma classe de trabalhadores que pouco era estimada. A mídia tornou visível alguns dos trabalhos ocultos que compõem nossas experiências alimentares que, na maioria das vezes, aparecem de maneira romanesca e poética. Os consumidores destes programas, em geral, sentem-se encorajados e desafiados a cozinhar, por exemplo. Ao mesmo tempo, 


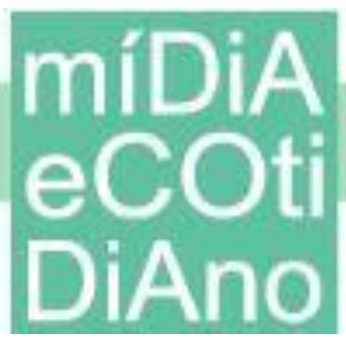

tem se observado nos dias atuais que o tempo gasto na cozinha está em declínio, ainda que a comida seja um crescente meio de entretenimento na mídia, ou seja, as pessoas adoram assistir outras pessoas cozinhando, mas isso não significa que elas gostem de cozinhar (COLLINS, 2009). Em outras palavras, a mídia é atraente para além do interesse dos indivíduos em aprender novas técnicas de culinária ou encontrar novas receitas para tentar executá-las em casa. Seu principal interesse está no desejo de consumir o alimento na forma de espetáculo.

Por trás de um prato gourmet bem preparado, há um trabalho "invisível” para criar o espetáculo visual nas telas. Considera-se que este trabalho nos bastidores envolve uma equipe de produtores culinários que são responsáveis por todos os detalhes de um episódio, desde a entrada e saída de pratos, elaboração de receitas em diferentes etapas de conclusão, até os ingredientes e utensílios que precisam estar disponíveis (GUPTILL; COPELTON; LUCAL, 2013). Assim, mesmo que o programa mostre os conflitos, os imprevistos ou conversas casuais que acontecem entre os participantes, o que é apresentado aos espectadores se reduz a uma sequência de imagens pensadas e cuidadosamente construídas.

Desse modo, é importante refletir sobre a seguinte questão: O que torna um programa de entretenimento alimentar atraente mesmo para aqueles que não cozinham? Quais elementos podem ser identificados para avaliar a adesão desses consumidores? Como entender esse fenômeno social?

Partindo disso, considera-se que a televisão é indiscutivelmente a força mais poderosa que molda a paisagem culinária nos dias de hoje. Para compreender este fenômeno, alguns autores explicam que os espetáculos ao redor da comida são semelhantes, por exemplo, à pornografia, uma vez que, baseados nas fantasias e fetiches do público consumidor, são projetados para induzir o desejo.

O fenômeno conhecido por "pornografia alimentar" ou food porn, demonstra que os elementos voyeuristas da mídia no entretenimento alimentar parecem ser tão deslocados e distantes da vida real que não podem ser alcançados, exceto por uma experiência vicária (GUPTILL; COPELTON; LUCAL, 2013). Na verdade, retratos de comida foram tão transformados pelo estilo sofisticado que, cada vez mais, parece estar fora do alcance do cozinheiro ou do consumidor, tal como acontece na pornografia: se aprecia assistir o que 
supostamente não se pode fazer (MCBRIDE, 2010). A ideia se concentra em close-ups sensuais de comida envolvendo criações fantásticas que, como muitos cenários pornográficos estereotipados, provavelmente nunca se realizarão nas casas do público.

O semiólogo Roland Barthes (2009) discutiu o que é essencialmente pornografia alimentar quando mencionou a exposição de preparações culinárias destacadas na Revista Elle. Para Barthes, a "cozinhar, de acordo com a Revista Elle, é para o olho sozinho, uma vez que a visão é um sentido gentil", isto é, uma fantasia que conforta aqueles que não têm acesso às refeições de luxo (BARTHES, 2009, p. 78). A comida tem um apelo sensual, sendo reconhecida como um elemento positivo na vida cotidiana das pessoas, criando sensações prazerosas e associações, assim como o sexo que faz parte da vida de todos de alguma forma.

Em estudo mais recente, Ibrahim (2015) aponta que a pornografia alimentar alude à fetichização dos alimentos e à sua coalescência com o desejo, estilizando as ofertas culinárias para serem consumidas por públicos famintos. Este alimento deve ser consumido pela visão e por outros sentidos, evocando os desejos ocultos e destacando sua inatingibilidade. Sua qualidade pornográfica remove os alimentos do cotidiano e do comum, elevando-os ao nível do pornográfico. Ao mesmo tempo, as imagens de alimentos como uma forma de materialidade transacionada on-line oferecem familiaridade, conforto, co-presença, mas acima de tudo, uma alfabetização elementar comum, onde os alimentos transcendem as barreiras culturais, oferecendo um impulso universal em direção a uma mercadoria efêmera, mas preservada pela economia do clique. A comida é simbólica da solidariedade humana, da socialidade e do compartilhamento, e igualmente da diferença, criando um espetáculo e uma plataforma para conversas, convenções, conexões e consumo indireto. As imagens dos alimentos simbolizam a conexão à distância através da cultura e práticas materiais cotidianas (IBRAHIM, 2015).

Essa discussão também alcança o debate em torno da alimentação saudável. A exposição visual generalizada à comida demonstrou exercer um papel essencial no comportamento alimentar. Para Wansink (2006), as informações sobre alimentos derivadas da mídia digital influenciam mais de $70 \%$ dos alimentos consumidos pelos americanos. Desse modo, os programas de culinária, propagandas de alimentos e feeds de mídia social contendo imagens de alimentos de alta energia, podem oferecer uma fonte 
substituta de prazer, ao mesmo tempo em que indiretamente promovem o consumo excessivo e a gratificação (SPENCE et al., 2016).

\section{Cozinha midiática ou cozinha ornamental: a busca pelo inacessível}

Historicamente, o comer e o cozinhar podem ser oferecidos como um ato de estima, agradecimento, interesse ou como um objeto de pactos e conflitos. Ambos marcam tanto as semelhanças como as diferenças étnicas e sociais, classificam e hierarquizam as pessoas e os grupos, expressam formas de conceber o mundo e incorporam um grande poder de evocação simbólica.

$\mathrm{Na}$ maioria das vezes, quando se referencia os termos cozinha e culinária, normalmente é dada uma concepção mais estrita: manipulação de ingredientes, técnicas de preparo, procedimentos culinários, princípios de condimentação, entre outros. No entanto, Lévi-Strauss (2006) e outros autores, explicam que a cozinha e a culinária possuem um sentido muito mais amplo. Sob um enfoque estruturalista, o antropólogo Claude Lévi-Strauss (2006) trouxe amplas contribuições para o estudo da cultura e de sua relação com a alimentação. Em sua investigação antropológica junto aos indígenas brasileiros, utilizou os mitos como material de análise para compreender os modos de viver e pensar daqueles povos. Dentre suas observações, pôde concluir que a culinária é uma linguagem, pois é uma atividade universal, expressa em qualquer sociedade humana, constituída por um conjunto de signos e símbolos que se relacionam e configuram um sistema de traços culinários, em que cada cultura, de modo inconsciente, cria sua própria estrutura. Assim como a linguagem, a cozinha também é regrada, pois a regra é o elemento fundamental na caracterização da cultura. Portanto, para o autor a culinária é um sistema cultural alimentar. Este sistema cultural é modelizado pelas práticas alimentares, pelos elementos culturais e simbólicos de um determinado grupo social, configurando-se em subsistemas. Desse modo, existe uma cozinha que é universal - no sentido amplo - e cozinhas específicas de cada civilização (LÉVI-STRAUSS, 2006).

Com base nas reflexões de Lévi-Strauss, o sociólogo Claude Fischler (1995) aprofunda em sua obra El h'omnivoro o conceito de sistema cultural alimentar, como um desdobramento do conceito de culinária apresentado anteriormente pelo antropólogo. Fischler acrescenta um sentido mais específico e sintetiza que as representações, crenças 


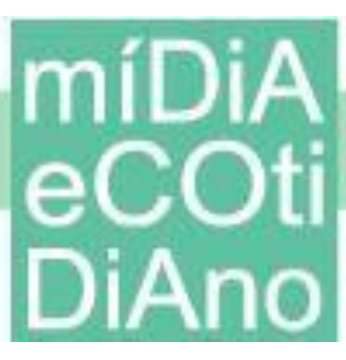

e práticas que formam uma cultura estão associadas à cozinha, na qual "cada cultura possui uma cozinha específica que implica em classificações, taxonomias particulares e um complexo de regras que atendem não apenas à preparação e combinação de alimentos, mas também a sua colheita e consumo" (FISCHLER, 1995, p. 34). Portanto, sistemas alimentares diferentes correspondem a sistemas culturais distintos.

Compreende-se, assim, que a cozinha não é um universo desordenado em que se joga todos os ingredientes em um caldeirão para que se ferva em um grande caldo universal. Ao contrário, a cozinha é um espaço de formas ordenadas, um sistema fechado, segundo as regras e rituais dotados por cada cultura. Em um exemplo prático, La Cecla (1998) explica que ao preparar uma massa, não se pode condimentá-la com qualquer molho ou casá-la com qualquer ingrediente, como acreditava o amigo alemão do autor, que preparava para os amigos espaguete com feijões estufados e pimentões crus. $\mathrm{O}$ pecado do alemão foi pressupor que a massa pode levar, entre as infinitas variações, uma variação a mais, como um sistema aberto e facilmente adaptável. Assim, apenas os falantes nativos daquela cozinha - confirmando que a comida é uma linguagem conhecem o território íntimo e delicado das variações consentidas além do qual esta preparação destoa como a piada de um estrangeiro, tão inovadora quanto desajeitada, em uma língua por ele não dominada (RIGOTTI, 2016).

A partir desse ponto, ao reconhecer a cozinha como cultura e, portanto, modelizada pelo sistema cultural alimentar, é por meio da multiplicação dos ambientes midiáticos que ocorre uma amálgama entre os sistemas da cultura das mídias com os sistemas da cultura da culinária e, também, da gastronomia. O sistema cultural constituído pela culinária é modelizado pelos meios de comunicação e vice-versa.

Assim, como argumenta Helena Jacob (2009), os ambientes midiáticos construídos por esse processo de modelização organizam uma espacialidade geradora de visualidade que vem modificando a imagem da gastronomia. Observa-se que tal espacialidade esteja modificando a relação do público com a comida e com a cozinha, construindo uma nova teia de relações simbólicas com o alimento, com o ato de cozinhar e com a própria mídia. Por conseguinte, a construção dos ambientes midiáticos na gastronomia tem feito que o sistema cultural operasse como mídia modeladora das preferências e gostos alimentares dos diferentes paladares sociais, culturais e econômicos. 
O espaço hoje construído na mídia não é o da dona de casa que precisa cozinhar para sua família diariamente [...] O que se observa é a construção de um ambiente midiático gastronômico do desejo, onde espaços gourmets, cozinhas de sonho, chefs celebridades e pratos exclusivos, entre outros, convivem com o alimento no seu puro aspecto nutricional (JACOB, 2009, p. 109).

São nestas espacialidades que visualizamos como funcionam as cozinhas midiáticas no âmbito dos reality shows voltados para gastronomia. Esta cozinha não está apenas associada à cozinha como um espaço físico, mas se refere à construção de um ideal de cozinha. Barthes (2009) quando analisou as imagens de alimentos produzidas pela Revista Elle, acrescentou que a representação da cozinha apresentada nos meios midiáticos é de uma concepção mítica, idealizada e inacessível para a maioria das pessoas. Entre os elementos que foram evidenciados na sua investigação, destaca-se que a superficialidade é a base da cozinha ornamental, feita para os olhos, puramente visual, "uma cozinha de sonho".

Elle é uma revista preciosa, pelo menos em termos lendários, cuja função é apresentar ao imenso público popular que é seu o sonho do chique; daí uma cozinha do revestimento e do álibi, que se esforça sempre por atenuar, ou mesmo mascarar, a natureza primeira dos alimentos, a brutalidade das carnes ou o inesperado dos crustáceos. O prato camponês só é admitido a título excepcional (o bom cozido familiar), como fantasia rural para citadinos esnobes (BARTHES, 2009, p. 131).

O alimento ali exposto não é real, é um simulacro, marcado pela distinção social das classes que podem ou não ter acesso àquele ideal. Investe-se em uma economia mítica, no qual se vende a ideia do consumo burguês como fim de distinção, gosto universal a ser perseguido: o sonho do chique ou o sonho do gourmet (JACOB, 2016).

No Masterchef Profissionais, a gourmetização é uma constante exigida em todas as provas do programa, associada quase sempre ao refinamento de pratos bem preparados à categoria da haute gastronomie ${ }^{4}$. Em entrevista a Nexo Jornal (CAROSELLLA, 2018), a jurada do Masterchef, Paola Carosella, expõe sua compreensão sobre o universo

\footnotetext{
${ }^{4}$ Haute gastronomie ou Haute cuisine, do francês, significa alta gastronomia que, iniciada na França no século XIX, evoca sofisticação de técnicas e preparações.
} 


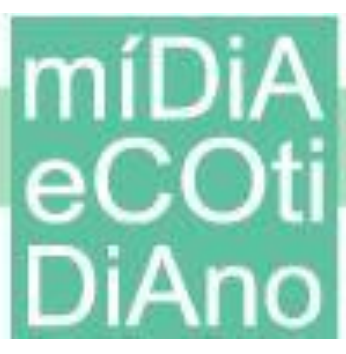

gourmet que afeta a gastronomia atualmente. Ela explica que a imprensa gastronômica levou todas as maravilhas da gastronomia muito exclusiva e as ampliou ao publicar isso nos jornais, na televisão ou nos sites de redes sociais, abrindo-se uma porta ao universo da gastronomia, uma parte que mostra a cozinha como uma coisa extremamente exclusiva, delicada e inacessível.

Uma coisa é a comida e outra é a gastronomia. Tem restaurantes que fazem comida mais cotidiana e que enxergam a comida por um lado mais social, mais simples, talvez de uma história de cozinhar de geração em geração e, também, tem chefs de cozinha que fazem estilos mais refinados, mais artísticos, que fazem alta gastronomia de uma forma mais complexa. Para esses chefs de cozinha dentro desses estilos, é necessário que existam tendências como a [gourmetização] porque são como as tendências da arte, da moda que precisam aparecer e esses movimentos que tem haver com o momento do mundo, com a globalização (CAROSELLA, 2018).

O papel que os veículos midiáticos desempenham no imaginário social, seja nas redes sociais ou nos reality shows, tem caminhado para a modelização de uma cozinha que não parece se importar, a priori, com o "fazer" comida, mas, com o "parece ser", ou seja, parecer ser ornamental, indefinido e com uma aparência ditada pela nouvelle cuisine ${ }^{5}$.

Diante disso, compreende-se que a cozinha midiática é a concretização do espetáculo, a consumação do sonho (não) vivido que atinge seus espectadores pelo que chamamos de "raio gourmetizador": aquilo que está vinculado a um status social, numa tentativa banal de valorizar o que se come. Isso impressiona não somente os restaurantes mais sofisticados, mas também os mais populares. Com a popularização da comida, sobretudo, da comida de rua, dos food trucks e dos restaurantes mais acessíveis, a categoria de gourmet busca fazer a comida ser vista de outra forma, isto é, mais cara e com um nome um pouco mais difícil de se pronunciar em que, muitas vezes, é exatamente a mesma coisa que uma comida categorizada como "não gourmet". Assim, sublinha-se que, como nos lembra Renata do Amaral (2013), "num mundo em que tudo é gourmet, nada é gourmet".

\footnotetext{
${ }^{5}$ Nouvelle cuisine foi um movimento que revolucionou a alta gastronomia e contribuiu para que a estética se firmassem na gastronomia moderna.
} 


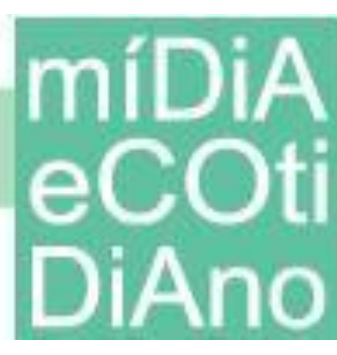

\section{Considerações finais}

Com base na multiplicação dos ambientes midiáticos, a cozinha foi modelizada pelos meios de comunicação ao migrar dos espaços convencionais dos lares e dos restaurantes para os espetáculos televisivos de gastronomia. Este movimento impulsionou, primeiramente, a visibilidade merecida a uma profissão que pouco era estimada - a gastronomia -, tornando visível o trabalho daqueles que se dedicam à arte gastronômica. Em segundo lugar, a construção de um ideal de cozinha mediada por imagens e, portanto, feita para os olhos, numa frágil concepção mítica que investe no comer pela via imagética, perseguido pela gourmetização, marcada pela distinção das classes sociais que podem ou não ter acesso àquele ideal. E, terceiro, os consumidores de cozinhas midiáticas não são apenas pessoas que possuem aptidão para cozinhar, mas integra também sujeitos motivados pelo desejo de consumir a comida na forma de espetáculo.

Este cenário de prevalência da gastronomia midiatizada nos leva ao fenômeno da food porn que procura explicar elementos voyeuristas da mídia alimentar que estão distantes da vida real, como algo inacessível, que apenas fortalece um processo de fetichização do comer, tornando este objeto de desejo (e de consumo) mais interessante do que o próprio objeto. A sociedade tende a atuar pornograficamente, por meio de um desnudamento sem limites, em que tudo se deseja sentir rápido demais e nada se desfruta de forma singular e profunda. Nesta sociedade midiatizada, o que realmente importa é exibir-se e comercializa-se num mercado de imagens enquanto exposição e não representação. Desse modo, o mundo da transparência não permite que nada escape à visibilidade da mídia.

Nesta perspectiva, os reality shows contemporâneos de gastronomia que assumem um caráter de espetáculo utilizam o comer, o cozinhar e o jogar como estratégias convidativas que impulsionam as pessoas a aderirem esse tipo de programa para a vida cotidiana. O Masterchef, por exemplo, é mais do que um programa de entretenimento, pois oportuniza a abertura de reflexões sobre a importância do cozinhar para si e para outro.

Desse modo, a hipervisibilidade dada aos programas de gastronomia tem refletido na tomada de decisões das pessoas sobre o comer e o cozinhar e, de forma mais ampla, sobre as vias de alimentação de uma sociedade, ao considerar o que as pessoas comem e os significados que atribuem às atividades de preparação e consumo dos alimentos. 


\section{miDiA
eCOti
DiAno}

\section{Referências}

AMARAL, Renata Maria do. Contra a gourmetização da vida. Art Fliporto - Revista de cultura e ensaios, v.3, p. 118-123, 2013.

BARTHES, Roland. Cocina ornamental. In: BARTHES, Roland. Mitologías. Madri: Siglo XXI, p.78, 2009.

BOURDIEU, Pierre. A distinção: crítica social do julgamento. São Paulo: Edusp; Porto Alegre: Zouk, 2007.

BRAGA, José Luiz. Mediatização como processo interacional de referência. Revista Animus, v. 5, n. 2, p. 9-35, 2006.

CAROSELLA, Paola. A história do gourmet. [19 de jan de 2018]. Youtube: Nexo Jornal. Entrevista concedida a Paola Carosella.

COLLINS, Kathleen. Watching What We Eat: The evolution of television cooking shows. New York: Continuum, 2009.

DEBORD, Guy. A Sociedade do Espetáculo. Rio de Janeiro: Contraponto, 1997.

DORTIER, Jean-François. Dicionário de Ciências Humanas. São Paulo: WMF Martins Fontes, 2010.

FISCHLER, Claude. El (h)omnívoro: el gusto, la cocina y el cuerpo. Barcelona: Editorial Anagrama, 1995.

RIGOTTI, Francesca. A filosofia na cozinha. São Paulo: Ideias \& Letras, 2016.

GOMES, Pedro Gilberto. Midiatização: um conceito, múltiplas vozes. Revista Famecos, v. 23, n. 2, p. 1-21, 2016.

GUPTILL, Amy E.; COPELTON, Denise A.; LUCAL, Betsy. Food and Society: Principles and Paradoxes. Malden, MA: Polity Press, 2013.

IBRAHIM, Yasmin. Pornografia gastronômica e o convite ao olhar: consumo efêmero e o espetáculo digital. International Journal of E-Politics, v. 6, n. 3, p.1-12, 2015.

JACOB, Helena Maria Afonso. A comida digital: um estudo dos ambientes midiáticos da cozinha nos blogs. In: CONGRESSO BRASILEIRO DE CIêNCIAS DA COMUNICAÇÃO, 32., 2009, Curitiba. Anais [...]. São Paulo: Intercom, 2009. Disponível em:

http://www.intercom.org.br/papers/nacionais/2009/resumos/R4-1448-1.pdf. Acesso em: 1 maio 2020.

JACOB, Helena Maria Afonso. Gastronomia, culinária e mídia: estudos dos ambientes midiáticos e das linguagens da comida e da cozinha. 2013. 207 f. Tese (Doutorado) - Curso de Comunicação e Semiótica, Programa de Pós-graduação em Comunicação e Semiótica, Pontifícia Universidade Católica de São Paulo, São Paulo, 2013.

JACOB, Michelle. O sabor em Roland Barthes: literatura e alimentação. In: MARQUES, Alfredo Henrique Oliveira. Barthes (im)pensado. Natal: Editora do IFRN, 2016.

JENKINS, Henry. A Cultura da Convergência. 2 ed. São Paulo: Aleph, 2009. 
KARPIK, Lucien. L'économie des singularités. Paris: Gallimard, 2007. Resenha de: Marie Anne Najm Chalita. Resenha do livro: O mercado das singularidades. Revista de Economia Agrícola, São Paulo, v. 55, n. 1, p.107-115, 2008.

KILPP, Suzana. Audiovisualidades do voyeurismo televisivo. Porto Alegre: Zouk, 2008.

LA CECLA, Franco. La pasta e la pizza. Bolonha: II Mulino, 1998.

LAVINAS, Eleonora Leite Costa. A narrativa "espetacularizada" dos reality shows de gastronomia. In: Congresso Brasileiro de Ciências da Comunicação, n. 38, 2015. Rio de Janeiro, Anais... [online], 2015.

LAZARSFELD, P. F; BERELSON, B; GAUDET, H. The peoples's choice: how the voter makes up his mind in a presidential campaign. 3. ed. New York: Columbia University Press, 1969.

LÉVI-STRAUSS, Claude. A origem dos modos à mesa (mitológicas 3). São Paulo: Cosac Naify, 2006.

LIEBES, Tamar; KATZ, Elihu. The export of meaning: Cross-Cultural Reading of "Dallas". 2. ed. Cambridge: Polity Press, 1993.

LIPOVETSKY, Gilles. A era do vazio: ensaio sobre o individualismo contemporâneo. Lisboa: Relógio D’Água, 1989.

MARCONDES FILHO, Ciro (Org). Dicionário de comunicação. São Paulo: Paulus, 2009.

MCBRIDE, Anne E. Food porn. Gastronomica: The Journal of Food and Culture, v.10, n. 1, p.38-46, 2010.

MORIN, Edgar. O desafio humano da comunicação. In: PENA-VEGA, Alfredo; et. al. (Orgs.). Edgar Morin: ética, cultura e educação. São Paulo: Cortez, 2003.

SANT'ANNA, Denise Bernuzzi. Bom para os olhos, bom para o estômago: o espetáculo contemporâneo da alimentação. Pro-Posições, v. 14, n. 2, p. 41-52, 2003.

SPENCE, Charles et al. Eating with our eyes: From visual hunger to digital satiation. Brain and Cognition, v. 110, p. 53-63, 2016.

THOMPSON, Jonh. A mídia e a modernidade: uma teoria social da mídia. 5. ed. Petrópolis, RJ: Vozes, 1998.

TONIN, Juliana. O espetáculo não é o coveiro da razão: mídia e autonomia em Gilles Lipovetsky. In Texto (UFRGS Online), n. 31, p.1-15, 2014.

WANSINK, Brian. Gatekeepers nutricionais e a solução de 72\%. Journal of the American Dietetic Association, v. 106, n. 2006, p. 1324-1327, 2006. 